\title{
Implementasi $K-N N$ Dalam Analisa Sentimen Riba Pada Bunga Bank Berdasarkan Data Twitter
}

\author{
Rasenda ${ }^{1}$, Hendarman Lubis ${ }^{2}$, Ridwan ${ }^{1, *}$ \\ ${ }^{1}$ Ilmu Komputer, STMIK Nusa Mandiri, Jakarta, Indonesia \\ ${ }^{2}$ Teknik, Teknik Informatika, Universitas Bhayangkara Jakarta Raya, Jakarta, Indonesia \\ Email: ${ }^{1}$ rasenda25@gmail.com, ${ }^{2}$ hendarman.lubis@dsn.ubharajaya.ac.id, 3," ${ }^{*}$ ridwans70@ gmail.com \\ Email Penulis Korespondensi: ridwans70@gmail.com
}

\begin{abstract}
Abstrak-Penelitian ini bertujuan untuk merumuskan pendapat masyarakat tentang bunga bank termasuk dalam kategori riba atau bukan. Metode yang digunakan dalam penelitian ini adalah analisis sentimen riba pada bunga bank menggunakan data twitter dengan algoritma $K-N N$. Analisis sentimen menggunakan algoritma $K-N N$ memberikan hasil yang baik. Terbukti dengan pengujian 170 dataset twitter menggunakan algoritma $K-N N$ memperoleh akurasi $\pm 70.59 \%$. Dibantu proses preprocessing yang bertujuan untuk menghapus bagian yang tidak penting dan juga mengubah bentuk dokumen yang berbentuk tweet ke bentuk standar agar pengklasifikasian dapat dilakukan, sehingga hasil dari analisis sentimen riba pada bunga bank dapat memperjelas asumsi didalam masyarakat dan dijadikan referensi dalam menentukan produk perbankan yang sesuai dengan kebutuhan nasabah.
\end{abstract}

Kata Kunci: Sentimen, Riba, Bank, Twitter, $K-N N$

\begin{abstract}
This study aims to formulate public opinion about bank interest included in the category of usury or not. The method used in this study is the analysis of usury sentiments on bank interest using Twitter data with the K-NN algorithm. Sentiment analysis using the K-NN algorithm gives good results. Evidenced by testing 170 twitter dataset using the K-NN algorithm obtained an accuracy of $\pm 70.59 \%$. Assisted by the preprocessing process which aims to erase unnecessary parts and also change the form of documents in the form of tweets to a standard form so that classification can be carried out, so that the results of usury sentiment analysis on bank interest can clarify assumptions in the community and serve as a reference in determining appropriate banking products to the needs of customers.
\end{abstract}

Keywords: Sentiment, Usury, Bank, Twitter, K-NN

\section{PENDAHULUAN}

Lembaga perbankan memiliki peranan yang sangat strategis di dalam menciptakan iklim yang kondusif, khususnya bagi peningkatan perekonomian nasional. Namun pada praktiknya masih banyak masyarakat yang bingung apakah transaksi melalui perbankan dan bunga bank termasuk riba. Penelitian ini bertujuan memperjelas asumsi masyarakat tentang riba pada bunga bank dan dapat dijadikan referensi dalam menentukan produk perbankan yang sesuai dengan kebutuhan nasabah menggunakan algoritma $K-N N$. Dalam penelitian terkait, yaitu "Majdalawieh, M., Marir, F., \& Tiemsani, I. (2018). Developing Adaptive Islamic Law Business Processes Models for Islamic Finance and Banking by Text Mining the Holy Qur'an and Hadith" telah dijelaskan untuk menganalitik riba dengan text mining menggunakan Qur'anic financial corpus, maka penulis akan menganalitik riba dengan text mining menggunakan sentimen tweet pada tweeter tentang riba pada bunga bank.

Sejumlah besar keuangan konvensional lembaga, terutama bank sedang bergerak ke model keuangan Islam yang sesuai dengan Hukum Syariah dengan sedikit perubahan pada praktik konvensional saat ini (membutuhkan engineer dalam bisnis) untuk mengakomodasi pasar keuangan Islam[1].

Temuan akan dinilai dan dievaluasi menggunakan Qur'anic Financial Corpus dan menggunakan pendekatan komputasi dan analitik untuk text mining dalam Qur'an dan Hadits untuk menemukan pengetahuan tersembunyi tentang proses bisnis keuangan Islam.[1] punya.[2]

Minat sebagai proksi riba akan mempengaruhi semua orang, apa pun jenis pekerjaannya yang mereka

Berdasarkan analisis sensitivitas yang menunjukkan tingkat dalam hubungan, pedagang memiliki lebih banyak hubungan dengan tingkat bunga daripada petugas bank syariah[2].

Peningkatan konsentrasi di sektor perbankan konvensional dapat menyebabkan penurunan stabilitas melalui kenaikan harga. Untuk bank syariah, peningkatan kekuatan pasar secara positif dapat mempengaruhi stabilitas perbankan[3].

Karena "bunga" adalah istilah bahasa Inggris dan "riba" adalah bahasa Arab, menggabungkan keduanya membingungkan, terutama ketika lembaga keuangan Islam mengklaim untuk mempraktikkan keuangan "bebas bunga" dalam operasi mereka[4].

Rezim pembangunan yang memenuhi kehidupan, kesejahteraan, dan keberlanjutan. Hanya pengamatan statistik antara perdagangan dan riba tidak menunjukkan dampak sosial dan moral riba yang merendahkan. Sebaliknya, fakta statistik menunjukkan bahwa tabungan bank dapat meningkat bahkan dalam menghadapi penurunan suku bunga[5].

Twitter, dengan lebih dari 313 juta1 pengguna aktif bulanan dan lebih dari 500 juta tweet per hari2, kini telah menjadi tambang emas bagi organisasi dan individu yang memiliki minat sosial, politik atau ekonomi yang kuat dalam mempertahankan dan meningkatkan pengaruh dan reputasi mereka[6]. 
Analisis sentimen adalah proses mendeteksi secara otomatis apakah segmen teks mengandung konten emosional atau pendapat, dan selanjutnya dapat menentukan polaritas teks[6].

Twitter adalah tambang emas data dengan lebih dari 1/60 populasi dunia menggunakannya yang hampir berjumlah 100 juta orang, lebih banyak lebih dari setengah miliar tweet di-tweet setiap hari dan jumlahnya terus bertambah setiap hari[7].

Pengembangan infrastruktur TI secara keseluruhan yaitu Sistem Penyelesaian Bruto Nyata (RTGS), Lembaga Kliring Otomatis (ACH), Sistem Penyelesaian Sekuritas (Scripsless Security Settlement System / SSSS) dan Nomor Rekening Bank Internasional (IBAN) untuk proses otentikasi dan jaringan bank meta internasional Pembayaran Euro Tunggal. Area (SEPA) dan juga jaringan perbankan terintegrasi internasional termasuk Perhimpunan Telekomunikasi Keuangan Antar Bank Seluruh Dunia (SWIFT) dan Jaringan Transfer Informasi Antar Bank (Shetab), dan upaya-upaya lain yang dilakukan tidak efisien dalam menyerap kontribusi internasional untuk pembiayaan proyek melalui dana valuta asing di negara yang berbeda, mekanisme pembayaran elektronik yang memuaskan dalam sistem portal informatif untuk proyek investasi lemah[8].

Media sosial saat ini adalah sesuatu yang tidak mungkin terpisah dari setiap orang, seperti Instagram, twitter, facebook, path, line dan banyak lagi. Setiap orang memiliki setidaknya 2 hingga 5 akun media sosial di ponsel cerdasnya. Dari fenomena ini, menjadikan media sosial sebagai sumber data yang dapat digunakan untuk mencari opini publik secara instan[9].

Analisis sentimen ada beberapa tahapan, yaitu pengumpulan data sentimen menggunakan API (Aplikasi Programming Interface) yang tersedia di Twitter dan tahap preprocessing kemudian diproses untuk diproses mentah awal data, kemudian lakukan penandaan POS dan menimbang kata dengan Perhitungan TF-IDF.[10]

Data opini di Twitter yang digunakan untuk tentukan apakah data opini yang dimasukkan positif atau sentimen negatif menggunakan tiga kelompok berbeda untuk mengekstraksi pikiran atau perasaan pengguna melalui tweet dan kelompokkan mereka ke dalam kategori yang berbeda dengan bandingkan hasil untuk mengetahui penggolong yang memberikan hasil terbaik[11].

Text mining bertujuan untuk menghasilkan klasifikasi pada sentimen berdasarkan sumber data komentar publik di Facebook dan twitter di Indonesia dengan hasilnya positif dan negatif, sentimen didasarkan pada periode waktu dan jenis data[12].

\section{METODE PENELITIAN}

\subsection{Tahapan Penelitian}

Dalam menganalisis sentimen, langkah-langkahnya terdiri dari Pengumpulan dan Pelabelan Data, Preprocessing, dan Cof sentiment analysis. Gambar 1 menunjukkan langkah-langkah dalam analisis klasifikasi sentimen analisis yang diusulkan.

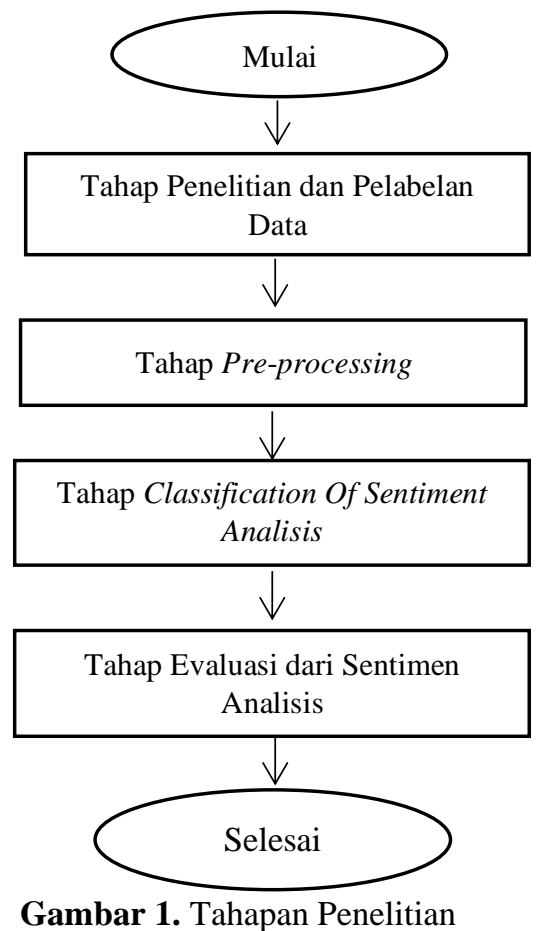

\subsection{Penelitian dan Pelabelan Data}


JURNAL MEDIA INFORMATIKA BUDIDARMA

Volume 4, Nomor 2, April 2020, Page 369-376

ISSN 2614-5278 (media cetak), ISSN 2548-8368 (media online)

Available Online at https://ejurnal.stmik-budidarma.ac.id/index.php/mib

DOI 10.30865/mib.v4i2.2051

Pada tahap pertama melaksanakan proses analisis sentimen adalah pengumpulan data. Data diambil dari Twitter dengan permintaan pencarian tentang riba bank sebanyak 170 dataset menggunakan aplikasi rapidminer.

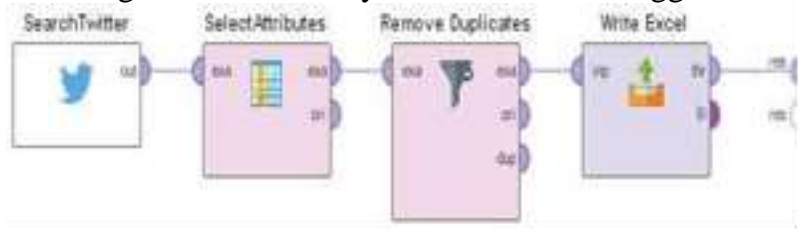

Gambar 2. Klasifikasi Data Retrieval

Gambar 2 menunjukkan pengambilan data dari Twitter menggunakan operator "search twitter" dan menyimpan data dalam file excel menggunakan operator "Write Excel" dengan hanya mengambil teks dari tweet dan menghapus semua tweet duplikat dengan operator "remove duplicate". Tahap selanjutnya adalah memberi label. Pelabelan dilakukan dengan mengelompokan data menjadi beberapa kelas sentimen yang digunakan yaitu positive dan negative. Tujuan proses pelabelan adalah untuk mengelompokan dataset menjadi dua bagian, untuk jadi data training dan data testing. Data training adalah data untuk melatih sistem agar mengenali pola yang diinginkan, sedangkan data testing adalah data untuk menguji hasil pelatihan yang dilakukan. Berikut ini adalah contoh dataset yang telah diberi label:

Tabel 1. Contoh Pelabelan

\begin{tabular}{|c|c|}
\hline Text & Sentimen \\
\hline $\begin{array}{l}\text { Insyallah dengan menabung di bank syariah terhindar dari riba. Riba sendiri dosanya } \\
\text { lebih besar dari zina dg ibu sendiri. ?? https://t.co/4135YaBn } 7 \mathrm{z}\end{array}$ & Positive \\
\hline "@fahiraidris Doakan kami bun Semoga bisa terlepas dari riba bank amiin" & Positive \\
\hline $\begin{array}{l}\text { @ AndyArch } 77 \text { Bani kadrun lagi buat ulah... pinjam uang dari bank riba dan haram, } \\
\text { tapi mereka tipu sana sini,,, tipu2 itu halal kah bagi mereka? }\end{array}$ & Negative \\
\hline $\begin{array}{l}\text { Yg teriak kerja di bank riba riba tpi masih pake promo grab ovo dana mending diem aj } \\
\text { dh https://t.co/WeynARqwYK }\end{array}$ & Negative \\
\hline
\end{tabular}

\subsection{Pre-Processing}

Setelah memberi label data, langkah selanjutnya adalah pre-processing. Yaitu tahap di mana data disiapkan untuk dianalisis. Beberapa tahapan dalam pre-processing, including cleansing, convert negation, convert emoticons, case folding, tokenization, filtering stopword dan stemming dalam bahasa Indonesia. Gambar 3 menunjukkan isi dari operator "Subprocess". Dalam hal ini, digunakan untuk "Remove URL", "convert negation", "convert emoticons".

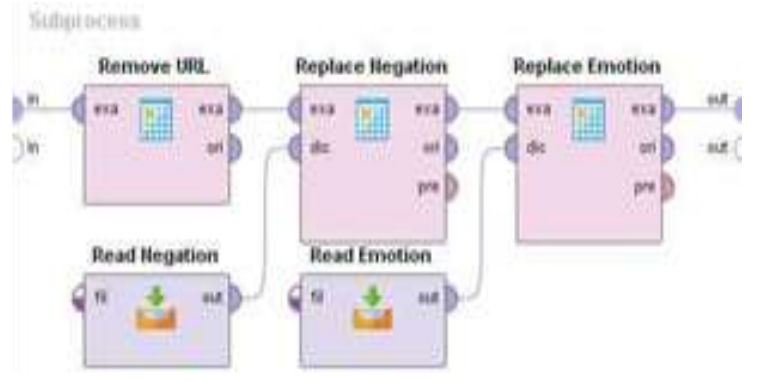

Gambar 3. Konten dari operator subprocess

Gambar 4 menunjukkan konten operator "Process Documents", yang digunakan oleh operator "transform cases", "tokenize”, "stopword filters" dan "stem" dalam bahasa Indonesia.

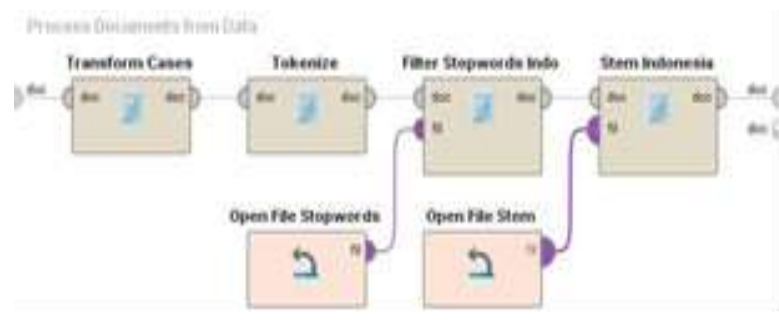

Gambar 4. Konten dari operator process document

Berikut ini adalah uraian terperinci tentang tahapan pre-processing di atas:

\subsubsection{Cleansing}


Cleansing adalah tahap di mana karakter dan tanda baca yang tidak diperlukan dihapus dari text. Ia bekerja untuk mengurangi noise pada dataset. Contoh karakter yang dihilangkan seperti URL, tag (\#), tanda baca seperti titik (.), Koma (,) dan tanda baca lainnya. Ini adalah contoh dari kalimat pembersihan data, masukan " Insyallah dengan menabung di bank syariah terhindar dari riba. Riba sendiri dosanya lebih besar dari zina dg ibu sendiri. ?? https://t.co/4135YaBn7z”, Kemudian output“" insyallah tabung bank syariah hindar riba dosa lebih besar zina ibu"

\subsubsection{Convert Negation}

Dalam bahasa Indonesia, ada kata "tidak", "tidak", "tidak", "kurang”, "tidak" yang disebut kata negasi yang merupakan kata yang dapat membalikkan makna kata yang sebenarnya. Ini adalah contoh negasi konversi kalimat, input" RT @KHMLuqman: Tidak riba. Mereka yg meribakan Bank harus belajar qiwaidul fiqh d ushul fiqH serta Maqashid syariah lbh dalam https://t.co/?”,output" rt @khmluqman: tidak_riba. mereka yg meribakan bank harus belajar qiwaidul fiqh d ushul fiqh serta maqashid syariah lbh dalam https://t.co/?".

\subsubsection{Convert Emoticon}

Emosi adalah ekspresi yang diwakili oleh kombinasi huruf, tanda baca, dan angka. biasanya emotikon digunakan untuk mengekspresikan suasana hati yang dirasakan. Convert Emoticons adalah salah satu cara untuk mengekspresikan ekspresi perasaan secara tekstual. Ini adalah contoh dari kalimat convert emoticon, input" Setelah ngejelasin latar belakang kampus ke user. ?? : Kamu siap kerja di bank? ?? : Iya lah anzeng ?? : Kamu ga takut riba? ?? : Ga bu, kenapa harus takut? ?? : Ya soalnya kan ada yang bilang riba haram ?? : Ga masalah buat saya, saya suka keharaman", output" setelah ngejelasin latar belakang kampus ke user. kesal : kamu siap kerja di bank? kesal : iya lah anzeng kesal : kamu ga takut riba? kesal : ga bu, kenapa harus takut? kesal : ya soalnya kan ada yang bilang riba haram kesal : ga masalah buat saya, saya suka keharaman". Berikut adalah salah satu contoh kata convert emoticon:

Tabel 2. Contoh Convert Emoticon

\begin{tabular}{|c|c|}
\hline Sebelum & Sesudah \\
\hline 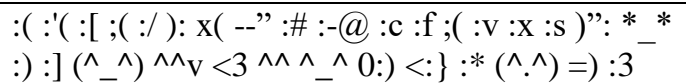 & $\begin{array}{l}\text { Sedih } \\
\text { Senang }\end{array}$ \\
\hline
\end{tabular}

\subsubsection{Case Folding}

Dalam menulis tweet, harus ada bentuk huruf yang berbeda, tahap ini adalah proses keseragaman huruf, keduanya adalah huruf kecil atau huruf besar. Ini adalah contoh case-folding sentence, input " RT @KHMLuqman: Tidak riba. Mereka yg meribakan Bank harus belajar qiwaidul fiqh d ushul fiqH serta Maqashid syariah lbh dalam https://t.co/?" dan output " rt @ khmluqman: tidak riba. mereka yg meribakan bank harus belajar qiwaidul fiqh d ushul fiqh serta maqashid syariah lbh dalam".

\subsubsection{Tokenization}

Suatu proses dengan memotong atau memecah kalimat menjadi beberapa kata-kata. Hasil deduksi disebut token. Dalam beberapa kasus, proses tokenization juga dengan menghilangkan tanda baca yang tidak perlu. Ini adalah contoh kalimat tokenization, input" RT @ KHMLuqman: Tidak riba. Mereka yg meribakan Bank harus belajar qiwaidul fiqh d ushul fiqH serta Maqashid syariah lbh dalam https://t.co/ק”, output rt khmluqman tidak riba mereka yg meribakan bank harus belajar qiwaidul fiqh d ushul fiqh serta maqashid syariah lbh dalam httpstco"'.

\subsubsection{Filtering}

Merupakan tahap menghilangkan kata-kata yang muncul dalam jumlah besar tetapi tidak memiliki makna (stopwords). Ini adalah contoh dari stopwords kalimat, input" Setelah ngejelasin latar belakang kampus ke user. ?? : Kamu siap kerja di bank? ?? : Iya lah anzeng ?? : Kamu ga takut riba? ?? : Ga bu, kenapa harus takut? ?? : Ya soalnya kan ada yang bilang riba haram ?? : Ga masalah buat saya, saya suka keharaman",output" ngejelasin latar kampus user. ?? : kerja bank? ?? : anzeng ?? : takut riba? ?? : bu, takut? ?? : bilang riba haram ?? : saya, suka keharaman".

Tabel 3. Contoh Stopwords

\begin{tabular}{|c|c|c|c|c|}
\hline ada & di & kalau & pada & yaitu \\
\hline aku & dia & kami & saja & bila \\
\hline bapak & ini & lalu & tentu & hari \\
\hline berbagai & itu & lewat & untuk & masa \\
\hline cara & jadi & meski & yang & tapi \\
\hline cuma & juga & oleh & wan & hal \\
\hline
\end{tabular}




\subsubsection{Stemming}

Stemming adalah tahap untuk menjadikan kata suffix menjadi kata-kata dasar sesuai dengan aturan Indonesia yang benar. Ini adalah contoh kalimat stemming, input " rt riba meribakan bank belajar qiwaidul fiqh ushul fiqh maqashid syariah lbh", output " rt riba riba bank ajar qiwaidul fiqh ushul fiqh maqashid syariah lbh". Berikut adalah contoh kata dari stemming :

Tabel 4. Contoh Kata Stemming

\begin{tabular}{ll}
\hline \multicolumn{1}{c}{ Sebelum } & \multicolumn{1}{c}{ Sesudah } \\
\hline adanya & ada \\
akhiri & akhir \\
sebelum & belum \\
diberikan & beri \\
secukupnya & cukup \\
dipergunakan & guna \\
\hline
\end{tabular}

\subsubsection{Weighting Word}

Weighting Word adalah mekanisme memberi skor kemunculan kata dalam dokumen teks dan untuk menghitungnya dapat menggunakan Persamaan

$$
t f-i d f_{t, d}=t f_{d} * i d f_{t}
$$

Term frequency (tf) adalah frequency occurrence (t) didalam document (d).

\subsection{Classification Of Sentiment Analysis}

Setelah pre-processing data, langkah selanjutnya adalah klasifikasi analisis sentimen. Tahap ini adalah tahap untuk memberikan pelatihan dan mengimplementasikan berbagai algoritma penambangan data. Gambar 5 menunjukkan isi dari operator "Cross-Validation" dalam aplikasi rapidminer. Dalam hal ini, menggunakan operator klasifikasi $K-N N$

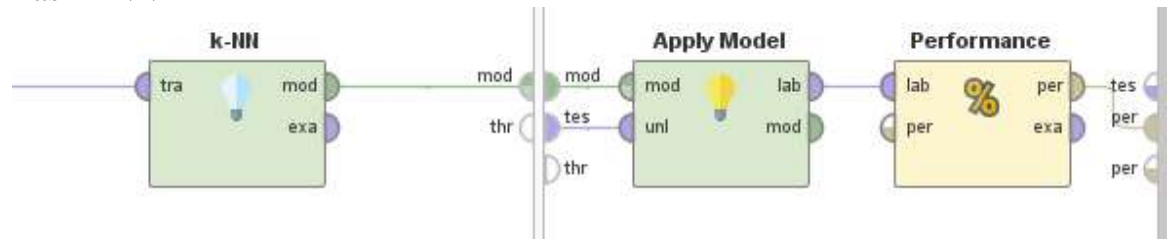

Gambar 5. Konten dari operator cross validation

Pemahaman lebih rinci dari $K-N N$ :

Algoritma K-Nearest Neighbor $(K-N N)$ adalah metode untuk mengklasifikasikan objek berdasarkan data pembelajaran yang paling dekat dengan objek. Oleh karena itu, untuk membuat prediksi dengan $K$ - $N N$, kita perlu mendefinisikan metrik untuk mengukur jarak antara titik kueri dan kasus dari contoh sampel. Salah satu pilihan paling populer untuk mengukur jarak ini dikenal sebagai Euclidean.

$$
\pi=1\left(x_{1}, f_{1}\right)=\sim \sqrt{x-p}
$$

Di mana $\mathrm{x}$ dan $\mathrm{p}$ masing-masing adalah titik query dan contoh kasus.

Karena prediksi $K$ - $N N$ didasarkan pada asumsi intuitif bahwa objek yang jaraknya dekat berpotensi sama, masuk akal untuk membedakan antara tetangga terdekat $\mathrm{K}$ ketika membuat prediksi. Biarkan titik terdekat antara tetangga terdekat $\mathrm{K}$ memiliki lebih banyak suara dalam memengaruhi hasil dari titik permintaan. Ini dapat dicapai dengan memperkenalkan seperangkat bobot $\mathrm{W}$, satu untuk masing-masing tetangga terdekat, yang ditentukan oleh kedekatan relatif masing-masing tetangga dengan memperhatikan titik permintaan.

$$
\sum_{i=1}^{x} W\left(x_{0} \cdot x_{1}\right)=1
$$

Jadi, untuk masalah klasifikasi, maksimum y diambil untuk setiap variabel kelas.

\subsection{Evaluasi dari Sentimen Analisis}

Setelah proses klasifikasi analisis sentimen selesai, diperlukan satu langkah lagi untuk menentukan kualitas proses yang telah dilakukan, yaitu mengevaluasi hasilnya. Pada tahap ini, perhitungan yang dilakukan akan diuji dengan parameter accuracy, precision, dan recall. Accuracly (A) adalah jumlah dokumen yang dikelompokan 
JURNAL MEDIA INFORMATIKA BUDIDARMA

Volume 4, Nomor 2, April 2020, Page 369-376

ISSN 2614-5278 (media cetak), ISSN 2548-8368 (media online)

Available Online at https://ejurnal.stmik-budidarma.ac.id/index.php/mib

DOI 10.30865/mib.v4i2.2051

dengan benar, baik Benar Positif maupun Benar Negatif. Menghitung nilai akurasi dapat menggunakan persamaan:

$$
\text { Accuracy }=\frac{(T N+T P)}{(T N+F N+T P+F N)} \times 100 \%
$$

Precision adalah berapa banyak hasil pemrosesan relevan dengan informasi yang dicari. Dapat juga diartikan, precision merupakan klasifikasi True Positive dan semua data diprediksi sebagai kelas positif. Untuk menghitungnya dapat menggunakan persamaan:

$$
\text { Precision }=\frac{T P}{(T P+F P)} \times 100 \%
$$

Sedangkan Recall (R) adalah berapa banyak dokumen yang relevan dalam koleksi yang dihasilkan oleh sistem. Dengan kata lain, recall adalah jumlah dokumen yang memiliki klasifikasi Benar Positif dari semua dokumen yang benar-benar positif (termasuk False Negative). Menghitung nilai recall dapat menggunakan persamaan:

$$
\text { Recall }=\frac{T P}{(T P+F N)} \times 100 \%
$$

Variabel seperti TP, TN, FP, dan FN berasal dari confusion matriks. Untuk penjelasan lebih rinci:

Tabel 5. Confusion Matrix

\begin{tabular}{ccc}
\hline & Prediksi Ya & Prediksi Tidak \\
\hline True Ya & TP & FN \\
True Tidak & FP & TN \\
\hline
\end{tabular}

Setelah data dikumpulkan, data akan dibagi menjadi data training dan data testing. Pembagian data akan dilakukan dengan menggunakan metode cross validation $\mathrm{N}$-fold untuk menghilangkan bias kata. Cross validation $\mathrm{N}$-fold membagi dokumen menjadi $\mathrm{n}$ bagian. Dalam satu set percobaan akan dilakukan $\mathrm{n}$ potongan percobaan klasifikasi dokumen dengan setiap percobaan menggunakan satu bagian sebagai pengujian data, (n-1) / 2 bagian sebagai dokumen berlabel, dan (n-1) / 2 bagian lain sebagai dokumen tidak berlabel yang akan ditukar setiap percobaan sebanyak n kali. Kumpulan dokumen yang dimiliki pertama kali disortir secara acak sebelum dimasukkan ke dalam flip. Hal ini dilakukan untuk menghindari pengelompokan dokumen dari satu kategori tertentu pada flip.

\section{HASIL DAN PEMBAHASAN}

Analisa Sentimen Riba Pada Bunga Bank Berdasarkan Data Twitter menggunakan algoritma $K-N N$ dilakukan dengan memasukkan dataset tweet pada twitter menggunakan tools, dimana dataset tersebut akan melalui tahap training, selanjutnya divalidasi dengan fitur cross validation, dan hasilnya dilihat di apply model.

\subsection{Pengolahan Dataset dengan Metode $K-N N$}

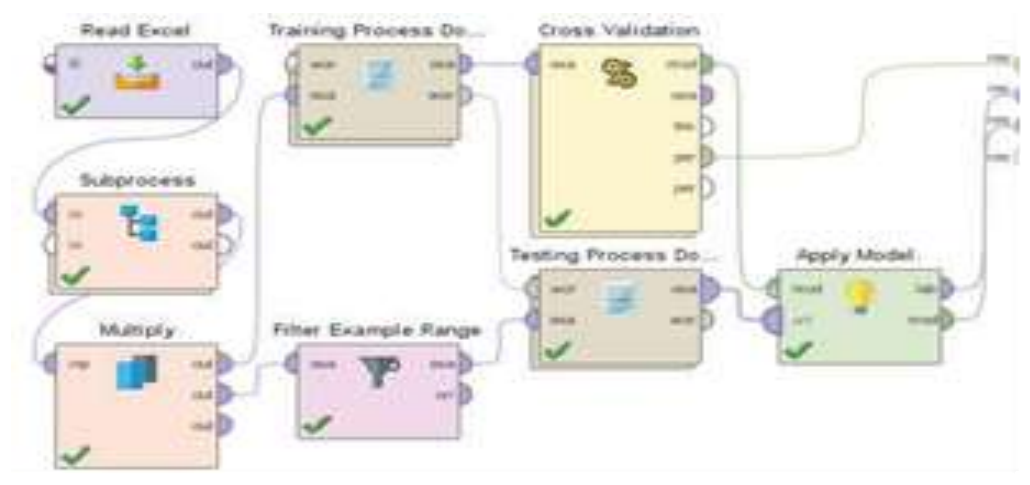

Gambar 6. Proses Utama Dari Rapidminer

Gambar 6 menunjukkan proses utama dalam aplikasi rapidminer. Operator "Read Excel" digunakan untuk membaca data dalam file Excel. Operator "Subprocess" dan operator "Document Process" digunakan untuk preprocessing. Operator "Cross Validation" digunakan untuk klasifikasi dan evaluasi analisis sentimen dengan eksperimen yang dilakukan sepuluh kali (validasi silang 10 kali lipat). 
JURNAL MEDIA INFORMATIKA BUDIDARMA

Volume 4, Nomor 2, April 2020, Page 369-376

ISSN 2614-5278 (media cetak), ISSN 2548-8368 (media online)

Available Online at https://ejurnal.stmik-budidarma.ac.id/index.php/mib DOI 10.30865/mib.v4i2.2051

\begin{tabular}{|l|l|l|l} 
sentimen & prediction(s... & confidence(negative) & confidence(positive) \\
negative & negative & 0.800 & 0.200 \\
negative & negative & 0.800 & 0.200 \\
\hline negative & negative & 0.800 & 0.200 \\
\hline negative & negative & 0.800 & 0.200 \\
\hline positive & negative & 0.800 & 0.200 \\
\hline negative & negative & 0.800 & 0.200 \\
\hline positive & negative & 0.800 & 0.200 \\
\hline negative & negative & 0.800 & 0.200 \\
negative & negative & 0.800 & 0.200 \\
negative & negative & 0.800 & 0.200
\end{tabular}

Gambar 7. Prediksi Hasil dari Rapidminer

Gambar 7 menunjukkan hasil prediksi dalam aplikasi rapidminer. Melihat pada sentimen dan juga label prediksi dari yang sama seperti label sentimen.

Berikut ini menjelaskan hasil confusion matriks algoritma $K-N N$ dari rapidminer:

Proses testing mendapatkan nilai auc sebesar 78,2\% yang dapat dilihat pada gambar 8 dibawah ini:

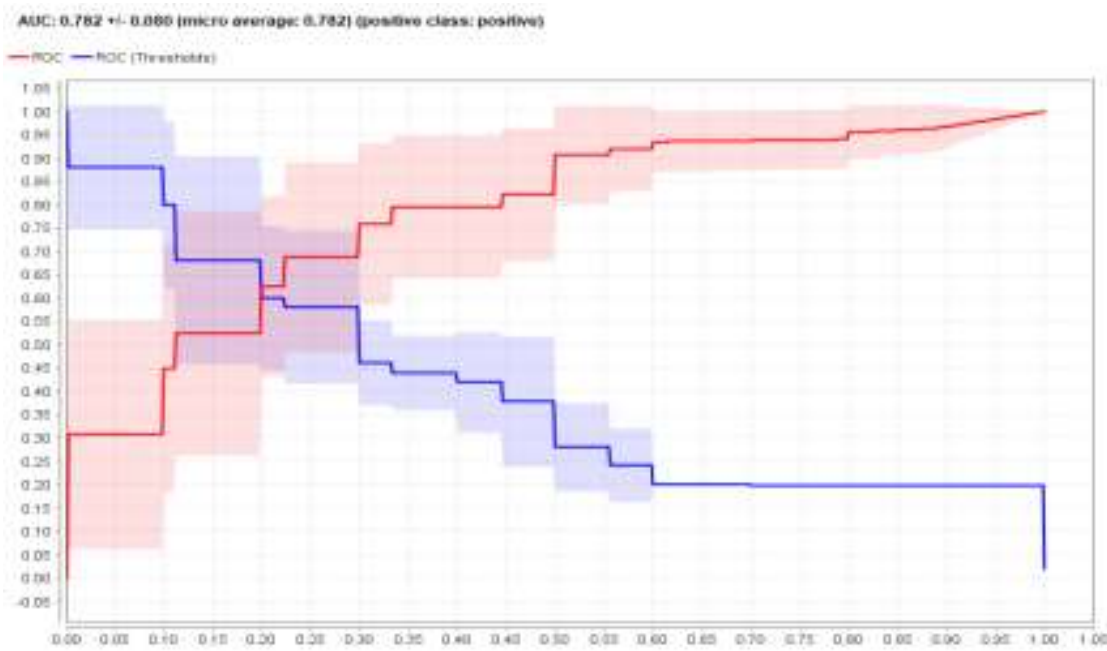

Gambar 8. Nilai AUC Dalam Grafik ROC

Pengujian menggunakan metode $K-N N$ mendapatkan nilai confusion matrix sebagai berikut :

True Positive $(T P)=46$ record

True Negative $(T N)=74$ record

False Positive $(F P)=28$ record

False Negative $(F N)=22$ record

\begin{tabular}{|lll} 
& true negative & true positive \\
\hline pred. negative & 74 & 28 \\
\hline pred. positive & 22 & 46 \\
\hline
\end{tabular}

Gambar 9. Hasil Confusion Matrix

Dari matriks konfigurasi pada gambar 9, nilai rata-rata akurasi, precision dan penarikan ditampilkan pada tabel 6 dengan perhitungan menggunakan rumus (4), (5), (6).

Tabel 6. Nilai dari Accuracy, Precision, dan Recall

\begin{tabular}{cccc}
\hline metode & accuracy & precision & Recall \\
\hline$K-N N$ & $70,59 \%$ & $69,87 \%$ & $62,32 \%$ \\
\hline
\end{tabular}

\footnotetext{
Accuracy $=\frac{(74+46)}{(74+22+46+22)} \times 100 \%$

$=70,59 \%$
} 
JURNAL MEDIA INFORMATIKA BUDIDARMA

Volume 4, Nomor 2, April 2020, Page 369-376

ISSN 2614-5278 (media cetak), ISSN 2548-8368 (media online)

Available Online at https://ejurnal.stmik-budidarma.ac.id/index.php/mib

DOI 10.30865/mib.v4i2.2051

Hasil ini menunjukkan Akurasi $K-N N$ 70,59\%. Hasil untuk Precision 69,87\%. Sementara hasil untuk Recall $K$ $N N 62,32 \%$. Jadi dapat dilihat bahwa classifier $K-N N$ cukup baik untuk digunakan dengan dataset media sosial karena memberikan prediksi yang lebih akurat dan tepat.

\section{KESIMPULAN}

Dalam penelitian ini, upaya dilakukan untuk mengklasifikasikan sentimen analisis dari tweet di Twitter pada berbagai pendapat tentang riba pada bunga bank di Indonesia. Untuk meringkas pandangan masyarakat tentang riba pada bunga bank, teknik penambangan teks digunakan, dan penambangan data menggunakan algoritma klasifikasi $K-N N$ untuk memprediksi label dalam dataset. Hasilnya menunjukkan Akurasi $K-N N 70,59 \%$. Hasil untuk Precision 69,87\%. Sementara hasil untuk Recall $K-N N$ 62,32\%. Jadi dapat dilihat bahwa classifier $K$-NN cukup baik untuk digunakan dengan dataset media sosial karena memberikan prediksi yang lebih akurat dan tepat. Di masa depan, kita harus menggunakan dataset yang lebih besar dan lebih kompleks dengan peningkatan jumlah label dan jangkauan sentimen tweet riba pada bunga bank yang lebih banyak dan dapat mencakup bahasa Indonesia non-standar.

\section{REFERENCES}

[1] M. Majdalawieh, F. Marir, and I. Tiemsani, "Developing Adaptive Islamic Law Business Processes Models for Islamic Finance and Banking by Text Mining the Holy Qur'an and Hadith," Proc. - 2017 IEEE 15th Int. Conf. Dependable, Auton. Secur. Comput. 2017 IEEE 15th Int. Conf. Pervasive Intell. Comput. 2017 IEEE 3rd Int. Conf. Big Data Intell. Compu, vol. 2018-Janua, pp. 1278-1283, 2018.

[2] A. Kafabih and A. Manzilati, "Analysis of Kafabih, A., \& Manzilati, A. (2018). Analysis of Preferable Occupation between Merchant and Islamic Bank Clerk in Bank Syariah Mandiri (BSM) Based on a Hadith about Riba. Iqtishadia, 11(2), 264. https://doi.org/10.21043/iqtishadia.v11i2.2751Pr," Iqtishadia, vol. 11, no. 2, p. 264, 2018.

[3] A. Louhichi, S. Louati, and Y. Boujelbene, "Market-power, stability and risk-taking: an analysis surrounding the ribafree banking," Rev. Account. Financ., vol. 18, no. 1, pp. 2-24, 2019.

[4] U. Suharto, "Riba and interest in Islamic finance: semantic and terminological 1ssue," Int. J. Islam. Middle East. Financ. Manag., vol. 11, no. 1, pp. 131-138, 2018.

[5] M. A. Choudhury, A. A. B. Rahman, and A. Hasan, "Trade versus riba in the Qur'ān with a critique of the role of banksaving," International Journal of Law and Management, vol. 60, no. 2. pp. 701-716, 2018.

[6] Z. Jianqiang and G. Xiaolin, "Comparison research on text pre-processing methods on twitter sentiment analysis," IEEE Access, vol. 5, no. c, pp. 2870-2879, 2017.

[7] A. Rane and A. Kumar, "Sentiment Classification System of Twitter Data for US Airline Service Analysis," Proc. - Int. Comput. Softw. Appl. Conf., vol. 1, pp. 769-773, 2018.

[8] B. Melli and M. Allahyarifard, "It-Based Usury Free Financial Innovations," vol. 4, no. 1, pp. 39-49, 2019.

[9] R. N. Chory, M. Nasrun, and C. Setianingsih, "Sentiment analysis on user satisfaction level of mobile data services using Support Vector Machine (SVM) algorithm," Proc. - 2018 IEEE Int. Conf. Internet Things Intell. Syst. IOTAIS 2018, pp. 194-200, 2019.

[10] F. S. Fitri, M. N. S. Si, and C. Setianingsih, "Sentiment analysis on the level of customer satisfaction to data cellular services using the naive bayes classifier algorithm," Proc. - 2018 IEEE Int. Conf. Internet Things Intell. Syst. IOTAIS 2018, pp. 201-206, 2019.

[11] A. Bayhaqy, S. Sfenrianto, K. Nainggolan, and E. R. Kaburuan, "Sentiment Analysis about E-Commerce from Tweets Using Decision Tree, K-Nearest Neighbor, and Naïve Bayes," 2018 Int. Conf. Orange Technol. ICOT 2018, pp. 1-6, 2018.

[12] Mihuandayani, E. Utami, and E. T. Luthfi, "Text mining based on tax comments as big data analysis using SVM and feature selection,” 2018 Int. Conf. Inf. Commun. Technol. ICOIACT 2018, vol. 2018-Janua, pp. 537-542, 2018. 